\title{
STUDI LITERATUR: EFEKTIVITAS MODEL KESIAPSIAGAAN BENCANA DI KOMUNITAS
}

\author{
I Made Moh. Yanuar Saifudin ${ }^{1,2}$, Ni Luh Seri Astuti ${ }^{\text {}}$, Novida Prima Wijayanti², \\ Marsha Yoke Nancy ${ }^{2}$, Ahmad Firdaus ${ }^{2}$, Uki Noviana ${ }^{2}$, Sri Warsini ${ }^{2}$ \\ ${ }^{1}$ STIKes Surya Global Yogyakarta
}

${ }^{2}$ Fakultas Kedokteran, Kesehatan Masyarakat dan Keperawatan Universitas Gadjah Mada Yogyakarta

\section{ARTICLE INFO \\ Article history}

Submitted : 2020-10-31

Revised : 2020-12-09

Accepted : 2021-07-26

\section{Keywords:}

Disaster preparedness Community

Training

\section{Kata Kunci:}

Kesiapsiagaan bencana Komunitas

Pelatihan

\begin{abstract}
Natural disasters occur all over the world and have massive effects. The impact of natural disasters has prompted various studies to find out the effects of a better mitigation and preparedness phase on individuals and communities in reducing the number of victims. Although revious literature are available that discuss disaster preparedness, studies that specifically assess the effectiveness of community-based disaster preparedness training are not available yet. This study aimed to identify effectiveness of community-based disaster preparedness training and which communication media are effective for use in disaster management in society. The literature reviews were conducted using the PRISM A model. The articles were collected from 4 journal databases, including EBSCO, Science Direct, Scopus dan ProQuest. Quality of each articles were assessed by Crowe Critical Appraisal Tool (CCAT). We identified a total of 3 studies. From the data extraction, 4 types of interventions were obtained in increasing disaster prep aredness including phone-based intervention, printed media intervention, peer-mentored preparedness (PM-Prep) program and small group discussion intervention. The effectiveness of community-based disaster preparedness training is evidence that is needed to be applied in various countries due to the high prevalence of natural disasters worldwide.

Bencana merupakan peristiwa yang dapat mengancam seluruh aspek kehidupan di dunia. Bencana dipengaruhi oleh kondisi fisik wilay ah serta kerentanan sosial, kultural, dan ekonomi. Kemajuan teknologi media informasi dan program pelatihan kesiapsiagaan bencana berbasis masyarakat dapat memotivasi kesiapan masyarakat dalam menghadapi bencana. Studi ini bertujuan untuk menilai teknik pelatihan berbasis masyarakat apa yang telah digunakan untuk kesiapsiagaan bencana alam dan media komunikasi mana yang efektif untuk digunakan dalam penanggulangan bencana. Penelitian ini menggunakan pendekatan studi literature review. Literature review dilakukan pada artikel yang diterbitkan pada jurnal peer-reviewed dalam 10 tahun terakhir. Pencarian dilakukan di 4 database jurnal, yaitu EBSCO, Science Direct, Scopus dan ProQuest. Kualitas studi dinilai dengan Crowe Critical Appraisal Tool (CCAT) dan hasil ulasan dihasilkan melalui proses narasi berulang dari hasil sintesis untuk mengidentifikasi tema umum, didapatkan hasil penelitian bahwa kesiapsiagaan bencana di komunitas bisa dilakukan dengan phone-based intervention, printed media intervention, peer-mentored preparedness (PM-Prep) program dan small group discussion intervention. Hasil dari studi literatur menunjukkan bahwa penting untuk menggunakan model kesiapsiagaan bencana yang berbasis komunitas baik berupa media elektronik maupun cetak, dan dengan metode peer-mentored maupun small group discussion untuk meningkatkan kemampuan masyarakat dalam kesiapsiagaan bencana.
\end{abstract}

\footnotetext{
$\triangle$ Corresponding Author:
}

Ni Luh Seri Astuti

Fakultas Kedokteran, Kesehatan Masyarakat dan Keperawatan Universitas Gadjah Mada Yogy akarta

Telp. 081338013383

Email: luhseriastuti12@gmail.com

\section{PENDAHULUAN}

Bencana terjadi di seluruh dunia dan mengakibatkan dampak yang masif. Pada tahun 2019, setidaknya terjadi 396 bencana alam dan telah menewaskan 11.755 orang serta memberikan dampak pada 95 juta orang dengan kerugian biaya hampir 130 miliar dolar US. Jumlah kejadian bencana tahun 2019 sedikit di 
atas rata-rata jumlah bencana pada 10 tahun terakhir. Peristiwa paling mematikan di tahun 2019 adalah gelombang panas yang mempengaruhi Eropa, lebih khusus Perancis, Belgia dan Belanda dengan lebih dari 2.500 kematian (CRED, 2020).

Laporan yang dirilis oleh International Federation of Red Cross and Red Crescent Societies (IFRC), pada tahun 2014, sebanyak 317 bencana alam yang dilaporkan di seluruh dunia, telah mempengaruhi 94 negara. Pada tahun 2014, terdapat 8.186 kematian dan 107.000.000 orang yang terkena dampak bencana. Selain itu pada tahun 2014, 48\% dari semua bencana di dunia terjadi di Asia (IFRC, 2015).

Dampak dari bencana alam telah mendorong berbagai penelitian tentang efek fase mitigasi dan kesiapsiagaan yang lebih baik pada individu dan masyarakat dalam mengurangi jumlah korban. Selain itu, investasi yang menjadi fokus pemerintah dan masyarakat saat ini, terdapat pada dua fase yaitu fase manajemen darurat dan fase ketahanan secara keseluruhan (de Vet et al., 2019).

Sementara, sumber daya yang ditujukan untuk memberikan informasi kepada masyarakat dan pelibatan masyarakat dalam penanggulangan bencana masih sangat kecil dan belum dilakukan evaluasi secara sistematis. Hal ini menyulitkan praktisi untuk menentukan teknik berbasis masyarakat tertentu yang dapat memberikan keberhasilan dalam meningkatkan kesiapsiagaan bencana di masyarakat (Ryan, 2017). Secara historis, upaya internasional untuk mengelola kesiapsiagaan darurat dimulai pada tahun 1950-an dan berfokus pada peristiwa bencana daripada membangun komunitas yang tahan bencana (Stehr, 2007).

Pelatihan kesiapsiagaan bencana mayoritas berbasis konvensional yakni berupa small group disscusion namun belum dibahas lebih jauh mengenai sejauh mana perannya mempengaruhi kesiapsiagaan masyarakat. Pada literature review sebelumnya yang membahas kesiapsiagaan bencana, yaitu pada sytematic review yang dilakukan oleh Potter et al., (2010), yang memberi informasi terkait biaya, manfaat, dan metode pelatihan kesiapsiagaan bencana. Namun sejauh penulis ketahui, studi yang secara khusus menilai efektifitas teknik pelatihan kesiapsiagaan bencana yang berbasis masyarakat dan media komunikasi mana yang efektif untuk digunakan dalam penanggulangan bencana masih belum tersedia.

Hasil dari studi literature review ini dapat meningkatkan kapasitas dan efisiensi tim pelibatan masyarakat dengan memberikan referensi untuk memilih teknik dan media yang sesuai dan telah terbukti memiliki tingkat efektifitas yang lebih besar dalam meningkatkan kesiapan menghadapi bencana.

\section{BAHAN DAN METODE Jenis Studi}

Penelitian ini merupakan literature review yang merupakan kajian pustaka dari berbagai penelitian orisinil (original research). Strategi pencarian artikel yang dilakukan adalah dengan menentukan terminologi pencarian (search term) berdasarkan metode Population, Intervention, Comparison and Outcome (PICO).

Adapun susunan PICO yang dipakai adalah Population: society OR civilization, Intervention: disaster preparedness training; Comparation dan Outcome: disaster awareness OR disaster preparedness OR disaster readiness. Search terms yang dilakukan "(Disaster Awareness OR Disaster preparedness OR Disaster Readiness) AND (society OR Civilization) AND Intervention AND Training”.

\section{Pengumpulan Data}

Pencarian dilakukan pada 4 database jurnal, yaitu EBSCO, ScienceDirect, Scopus dan ProQuest. Artikel yang diambil hanya yang dipublikasikan dalam bahasa Inggris, peerreviewed dan diterbitkan dalam 10 tahun terakhir. Dari artikel yang diperoleh, selanjutnya dilakukan skrining dengan membaca judul, keyword dan abstrak serta artikel yang memiliki kriteria inklusi.

Kriteri inklusi yang dimaksud, yaitu: a) tujuannya adalah menilai efektifitas pelatihan kesiapsiagaan bencana, b) responden diberikan tindakan pelatihan yang melibatkan masyarakat/berbasis komunitas, c) responden merupakan masyarakat berisiko terkena dampak bencana alam, d) desain studi merupakan observasional dan clinical trial, e) tersedia full-text artikel yang dapat diunduh. Sementara artikel bukan penelitian orisinil (original research), penelitian dengan desain kualitatif, dan literature review, dieksklusi. 


\section{Analisis Data}

Artikel yang terpilih dilakukan telaah kritis secara independent oleh peneliti dengan menggunakan Crowe Critical Appraisal Tool (CCAT) untuk menentukan kelayakan isi artikel. Pada awalnya, proses telaah kritis artikel dilakukan oleh 2 orang peneliti secara independen, dan didapatkan skor yang sama. Kemudian hasil ini didiskusikan secara panel kepada 3 peneliti lain dan disepakati skor akhir.

Ekstraksi data juga dilakukan secara independen dilakukan oleh 5 orang peneliti. Hasil ekstraksi terlebih dahulu dikumpulkan, kemudian dilanjutkan dengan diskusi panel terhadap temuan-temuan penting yang ada pada tiap artikel, termasuk pada karakteristik sampel, komponen intervensi, lama pemberian intervensi, pengukuran yang dipakai dan hasil intervensi. Pada akhir proses diskusi panel peneliti menggabungkan seluruh hasil ekstraksi data kedalam tabel sintesis yang membantu peneliti secara sistematis menentukan kesimpulan.

\section{HASIL PENELITIAN}

Pencarian literatur dari database EBSCO, Science Direct, Scopus dan ProQuest dengan limitation artikel yang dipublikasikan dalam bahasa Inggris peer-reviewed dan dalam 10 tahun terakhir, diperoleh sebanyak 861, selanjutnya dilakukan skrining berdasarkan judul, keyword dan abstraknya sehingga mendapatkan 29 artikel. Dari total 29 artikel tersebut, penulis melakukan seleksi berdasar full text dan dihasilkan 27 artikel yang dikeluarkan karena beberapa alasan diantaranya tidak berbasis komunitas sejumlah 13 artikel, tujuan tidak berhubungan dengan kesiapsiagaan bencana sejumlah 7 artikel, desain penelitian yang tidak sesuai yaitu kualitatif dan literature review sejumlah 4 artikel, serta bukan penelitian orisinil (original research) sejumlah 3 buah artikel.

\section{Bagan 1. Lite ratur Flowchart Berdas ar pada PRISMA Guidelines}

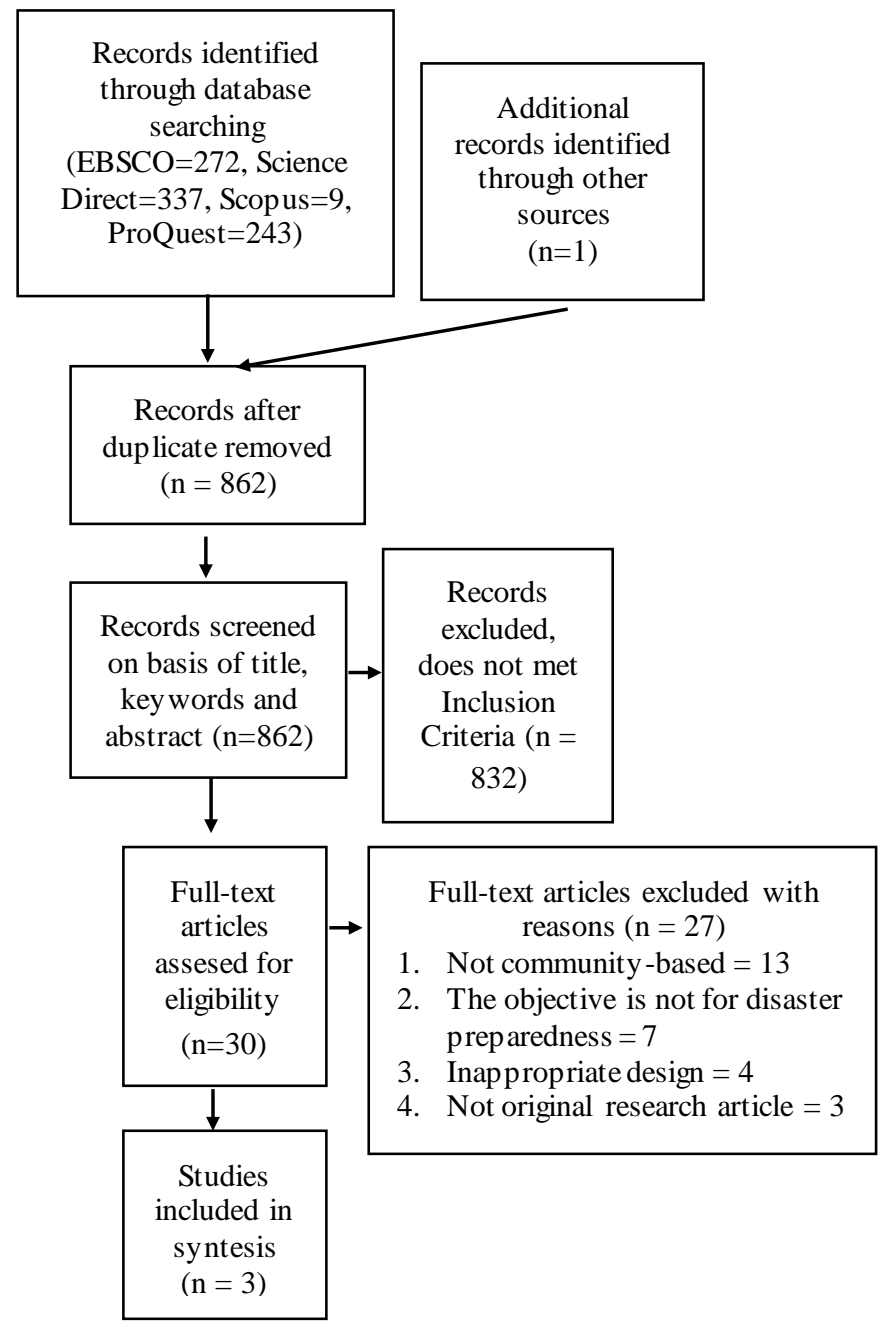


Berdasar proses tersebut, dihasilkan 2 artikel yang masuk dalam kriteria inklusi. Dari 2 artikel tersebut, penulis melakukan penelusuran pada referensi tiap artikel, didapatkan 1 artikel yang sesuai kriteria inklusi studi literatur ini dan kemudian ditambahkan kedalam proses analisis. Jadi, total keseluruhan artikel yang dilakukan sintesis adalah 3 artikel. Adapun alur proses pencarian dituangkan dalam alur diagram berdasarkan pada Preferred reporting items for systematic reviews and meta-analyses (PRISMA) 2009 Flow Diagram (Liberati et al, 2009).

Tiga artikel yang terpilih dilakukan penilaian kualitas menggunakan Crowe Critical Appraisal Tool (CCAT). Penilaian dilakukan dengan melihat poin tiap kategori untuk mencegah artikel penelitian yang dinilai mendapat skor tinggi secara keseluruhan tetapi sangat buruk dalam satu atau lebih kategori yang tersembunyi pada hasil total jika skor tiap kategori tidak dikaji. Didapatkan hasil total skor $29(73 \%), 30(75 \%)$, dan $31(78 \%)$ dengan ketentuan pada tiap kategori penilaian mendekati hasil nilai maksimal (skor 5) dimana semakin mendekati skor maksimal pada tiap poin yang dinilai maka hasilnya akan semakin baik. Dapat disimpulkan bahwa ketiga artikel yang didapatkan merupakan artikel yang baik. Ketiga artikel mendapatkan scor 73,75 dan 78 serta dinyatakan memiliki kualitas yang baik (Tabel 1).

\section{Tabel 1. Hasil Penilaian Kualitas Artikel dengan Crowe Critical Appraisal Tool (CCAT)}

\begin{tabular}{|c|c|c|c|c|c|c|c|c|c|c|c|}
\hline \multirow{2}{*}{ No } & \multirow{2}{*}{$\begin{array}{l}\text { Judul Artikel } \\
\text { (Sumber) }\end{array}$} & \multicolumn{8}{|c|}{$\begin{array}{c}\text { Hasil CCAT } \\
\text { Scoring Categories and Items }\end{array}$} & \multirow{2}{*}{$\begin{array}{l}\text { Total } \\
(/ 40)\end{array}$} & \multirow{2}{*}{$\begin{array}{c}\text { Total } \\
(\%)\end{array}$} \\
\hline & & $\begin{array}{l}\text { Prelimi } \\
\text { naries }\end{array}$ & $\begin{array}{l}\text { Introd } \\
\text { uction }\end{array}$ & Design & Sampling & $\begin{array}{c}\text { Data } \\
\text { Collection }\end{array}$ & $\begin{array}{l}\text { Ethical } \\
\text { Matters }\end{array}$ & Results & Discussion & & \\
\hline 1 & $\begin{array}{l}\text { Digital disparities } \\
\text { and vulnerability: } \\
\text { mobile phone use, } \\
\text { information } \\
\text { behaviour, } \\
\text { and disasterprepar } \\
\text { edness in Southeast } \\
\text { Asia (Lai et al., } \\
2018\end{array}$ & 4 & 3 & 4 & 3 & 3 & 4 & 4 & 4 & 29 & 73 \\
\hline 2 & $\begin{array}{l}\text { Peer-Mentored } \\
\text { Preparedness (PM- } \\
\text { Prep): A New } \\
\text { Disaster } \\
\text { Preparedness } \\
\text { Program for Adults } \\
\text { Living } \\
\text { Independentlyin } \\
\text { the Community } \\
\text { (Eisenman et al., } \\
\text { 2014) }\end{array}$ & 4 & 4 & 3 & 4 & 4 & 4 & 4 & 3 & 30 & 75 \\
\hline 3 & $\begin{array}{l}\text { Improving Latino } \\
\text { Disaster } \\
\text { Preparedness } \\
\text { Using Social } \\
\text { Networks } \\
\text { (Eisenman et al., } \\
\text { 2009) }\end{array}$ & 4 & 4 & 4 & 4 & 3 & 4 & 4 & 4 & 31 & 78 \\
\hline
\end{tabular}

Selain itu, dari ekstraksi data yang dilakukan, diperoleh 4 tipe intervensi dalam meningkatkan disaster preparedness, yaitu phone-based intervention, printed media intervention, peer-mentored preparedness (PMPrep) program dan small group discussion intervention (Eisenman et al., 2009; Lai et al., 2018; Eisenman et al., 2014). Adapun karakteristik studi dari artikel yang di ekstraksi, dijabarkan pada tabel 2 .
Teknik/media pelatihan kesiapsiagaan bencana berbasis masyarakat:

\section{Phone-Based Intervention}

Berbagi informasi terkait bencana dengan bantuan penggunaan teknologi smartphone seluler secara rutin secara signifikan berkaitan dengan perilaku kesiapsiagaan bencana yang baik. Selain penyediaan dukungan sosial terkait bencana, 
pemberian informasi dengan bantuan smartphone menjadi faktor yang memberikan pengaruh kuat terhadap peningkatan tingkat kesiapsiagaan. Sebaliknya, pengguna nonsmartphone cenderung hanya mengandalkan dukungan sosial khusus bencana sebagai motivator untuk kesiapsiagaan bencana. Penggunaan gawai dapat digunakan untuk menyebarluaskan informasi di komunitas. Lingkungan pedesaan dengan komunitas yang jarang penduduk dapat menggunakan gawai sebagai salah satu media untuk mngetahui informasi terkait bencana dan tindakan kesiapsiagaan yang berguna. Penelitian lanjutan perlu dilakukan untuk mengetahui fitur dan fungsi program pada gawai yang tepat untuk masyarakat urban atau daerah pedesaan untuk menerima dan menyebar luaskan informasi terkait kebencanaan (Lai et al., 2018).

\section{Tabel 2. Karakte ristik Studi}

\begin{tabular}{|c|c|c|c|c|c|}
\hline $\begin{array}{c}\text { Penulis, Tahun } \\
\text { dan Negara }\end{array}$ & Jumlah sampel & Jenis Intervensi & $\begin{array}{c}\text { Waktu } \\
\text { Pengamatan }\end{array}$ & Pengukuran & Hasil \\
\hline $\begin{array}{l}\text { Lai et al., } \\
\text { (2018) } \\
\text { Asia Tenggara }\end{array}$ & $\begin{array}{c}\text { 1,603 sampel } \\
(\mathrm{n}=402 \mathrm{di} \\
\text { Indonesia; } \mathrm{n}= \\
401 \text { di Filipina; } \\
\mathrm{n}=400 \mathrm{di} \\
\text { My anmar; } \mathrm{n}= \\
400 \text { di Vietnam). }\end{array}$ & $\begin{array}{l}\text { Phone-based } \\
\text { intervention. } \\
\text { - Melakukan/menerima } \\
\text { panggilan; } \\
\text { - Mengirim/menerima } \\
\text { pesan teks (SMS); } \\
\text { - Mendengarkan } \\
\text { radio/musik; } \\
\text { - Mengambil/mengirim } \\
\text { gambar atau video; } \\
\text { dan } \\
\text { - Menggunakan jam } \\
\text { alarm. }\end{array}$ & $\begin{array}{c}\text { Desember } \\
2014 \text { dan } \\
\text { Februari } \\
2015 .\end{array}$ & $\begin{array}{c}\text { Skala } \\
\text { McComas } \\
\text { dan Trumbo. }\end{array}$ & $\begin{array}{l}\text { Hasil menunjukkan } \\
\text { bahwa penggunaan } \\
\text { tekhnologi } \\
\text { smartphone seluler } \\
\text { secara rutin oleh } \\
\text { pengguna dan } \\
\text { persepsi risiko } \\
\text { mereka secara } \\
\text { signifikan berkaitan } \\
\text { dengan perilaku } \\
\text { kesiapsiagaan } \\
\text { bencana. }\end{array}$ \\
\hline $\begin{array}{c}\text { Eisenman et al., } \\
(2014) \\
\text { California, } \\
\text { USA }\end{array}$ & $\begin{array}{l}91 \text { partisipan, } \\
\text { diambil secara } \\
\text { acak untuk } \\
\text { kelompok } \\
\text { intervensi } 46 \\
\text { orang, dan } \\
\text { kelompok } \\
\text { control } 45 \text { orang. }\end{array}$ & $\begin{array}{l}\text { Program Peer-mentored } \\
\text { preparedness (PM- } \\
\text { prep). } \\
\text { Pelatihan manual } \\
\text { dengan mentor sebaya. } \\
\text { Setiap kelas berduarasi } \\
2 \text { jam dan kelas } \\
\text { diselenggarakan setiap } 2 \\
\text { kali seminggu selama } 2 \\
\text { minggu. }\end{array}$ & $\begin{array}{l}\text { September } \\
2010 \text { hingga } \\
\text { Januari } 2011\end{array}$ & $\begin{array}{c}\text { Ceklist } \\
\text { standar untuk } \\
\text { kesiapan } \\
\text { bencana. }\end{array}$ & $\begin{array}{l}\text { Kelompok intervensi } \\
\text { menunjukkan hasil } \\
\text { signifikan yakni } \\
\text { terdapat peningkatan } \\
\text { pengetahuan } \\
\text { kesiapsiagaan ( } 79 \% \\
\text { menjadi } 87 \%, \\
\text { p=0,001). }\end{array}$ \\
\hline $\begin{array}{l}\text { Eisenman et al., } \\
(2009) \\
\text { Los Angeles, } \\
\text { USA }\end{array}$ & $\begin{array}{l}231 \text { orang latin } \\
\text { y ang tinggal di } \\
\text { LA. Pada follow } \\
\text { up } 3 \text { bulan, total } \\
\text { partisipan } \\
\text { menjadi } 187 \\
\text { orang }(81 \%) \text {. }\end{array}$ & $\begin{array}{l}\text { Intervensi Small Group } \\
\text { Discussion (SGD) dan } \\
\text { media cetak. }\end{array}$ & $\begin{array}{c}\text { Dilakukan } \\
\text { pemberian } \\
\text { intervensi } \\
\text { pada } \\
\text { Februari- } \\
\text { Oktober } \\
2007 .\end{array}$ & $\begin{array}{c}\text { Ceklis } \\
\text { kesiapan } \\
\text { bencana yang } \\
\text { diisi mandiri. }\end{array}$ & $\begin{array}{l}\text { Kedua grup } \\
\text { menunjukkan } \\
\text { peningkatan } \\
\text { kesiapsiagaan } \\
\text { bencana. }\end{array}$ \\
\hline
\end{tabular}

\section{Printed Media Intervention}

Intervensi ini dilakukan dengan mengirim mail/pos yang berisi pamflet, kartu belanja berlaminasi, dan kartu komunikasi pracetak berlubang dengan instruksi tentang pembelajaran kesiapsiagaan bencana. Media yang diberikan berisi informasi tentang kesiapsiagaan bencana, meliputi hal-hal yang perlu dipersiapkan dalam menghadapi keadaan darurat. Media ini cukup mudah untuk dibuat dan tidak memerlukan pertemuan khusus kepada masyarakat, namun proses evaluasi perlu dilakukan secara berkala.

Pada studi ini, intervensi yang diberikan pada masyarakat dengan langsung memberikan media cetak ke rumah masingmasing. Hasil studi menunjukkan terjadi peningkatan yang signifikan pada pengetahuan dan aktifitas kesiapsiagaan bencana, termasuk rencana menyiapkan air bersih, makanan siap makan, kotak P3K, baterai ekstra, senter, selimut, makanan hewan peliharaan dan radio komunikasi (Eisenman et al., 2009). 


\section{Peer-Mentored Preparedness (PM-Prep) Program}

Peer-mentored preparedness (PMPrep) adalah pelatihan manual untuk bimbingan bersama rekan sebaya yang telah menjalani pengalaman tertentu. Peer-mentor bertindak sebagai asisten pelatih yang dapat mengundang para peserta atau anggota keluarga untuk menghadiri kursus. Pelatihan pada PM-prep ini memakan waktu selama dua jam per sesi dan diadakan dua kali seminggu selama dua minggu. Peserta diberikan pengajaran terkait kesiapsiagaan bencana oleh seorang penyuluh kesehatan dan mentor sebaya yang terlatih.

Kurikulum pelatihan dirancang untuk kebutuhan belajar orang dewasa yang memiliki disabilitas. Materi yang bersifat visual dan auditori diberikan lebih banyak dan dikombinasikan dengan kegiatan interaktif yang dipimpin oleh mentor sebaya.

Studi menunjukkan hasil signifikan pada kelompok intervensi, yakni terdapat peningkatan pengetahuan kesiapsiagaan pada masyarakat yang mendapatkan program peermentored. Peningkatan yang signifikan terjadi pada aktifitas kesiapsiagaan dan komunikasi yang direncanakan. Pada kelompok kontrol, terlihat tidak terjadi peningkatan signifikan pada nilai pengetahuan, akan tetapi terdapat sedikit peningkatan pada aktifitas kesiapsiagaan. Studi juga menunjukkan, tidak ada perbedaan nilai signifikan untuk usia, jenis kelamin, ras/etnik, atau hidup sendiri/bersama keluarga (Eisenman et al., 2014).

\section{Small Group Discussion Intervention}

Intervensi small group discussion (SGD) diberikan dalam 1 jam per sesi yang dipimpin oleh seorang promotor. Pada setiap sesi, peserta diberikan stimulus terkait hal-hal yang perlu dilakukan dalam kesiapsiagaan menghadapi bencana. Intervensi ini dilakukan secara interaktif oleh promotor untuk membantu peserta dalam mengembangkan rencana spesifik dalam menghadapi bencana, meliputi mempersiapkan air bersih, makanan, alat komunikasi radio, baterai cadangan, kotak P3K, senter, dokumen penting, obat pribadi yang diresepkan, makanan hewan peliharaan, selimut dan jas hujan.

Peserta diberikan stimulus untuk melakukan rencana darurat dan mendiskusikan tentang kemungkinan skenario dan komunikasi serta kesepakatan di antara anggota keluarga.
Promotor yang memimpin SGD memberikan bantuan yang diperlukan dalam mengklarifikasi ketidakpastian dan kesalahpahaman tentang rencana komunikasi. Penggunaan teknik small group discussion (SGD) oleh promotor terlatih dari manual yang dirancang khusus untuk peningkatan kesiapsiagaan bencana terbukti efektif bagi masyarakat dengan pendapatan rendah maupun ekonomi menengah keatas (Eisenman et al., 2009).

\section{PEMBAHASAN}

Kesiapsiagaan bencana yang baik dan kuat sangat diperlukan di masa sekarang dan masa yang akan datang karena kejadian bencana tidak bisa diprediksi oleh siapapun. Kesiapsiagaan terdiri dari tindakan, kegiatan, komunikasi, dan koordinasi yang dilakukan di seluruh sektor serta elemen untuk meningkatkan kapasitas masyarakat menghadapi bencana (Schwertner et al., 2018).

Komunikasi mendasari hampir semua elemen dari proses mitigasi bahaya. Kemampuan komunikasi, pengumpulan data, dan teknologi manajemen data telah melompat maju sejalan dengan peningkatan pengetahuan kita tentang asal-usul dan perilaku bahaya alam dan mitigasi dampaknya (Gupta, 2015).

Revolusi industri yang berbasis teknologi informasi mampu memberikan data secara cepat, tepat, mudah, dan praktis. Salah satunya adalah penggunaan mobile phone yang merupakan inovasi manajemen risiko bencana yang digunakan oleh lembaga pemerintah di sebuah negara. Penggunaan mobile phone yang dilengkapi dengan internet of things (IoT) memungkinkan masyarakat untuk dapat mengumpulkan dan berbagi infromasi, menganalisis, serta menggunakannya dalam protokol tindakan cerdas (Troy et al., 2008).

Sistem informasi yang terintegrasi sebagai hasil dari geo-informasi, sistem informasi geografi, global positioning system, dan Internet of Things (IoT) sangat efektif untuk memprediksi banjir sehingga dijadikan dasar dalam pengambilan keputusan yang tepat dalam penanggulangan bencana (Isfahani et al., 2019).

Hasil penelitian dari Isfahani et al, (2019) menyatakan bahwa telah berhasil mengembangkan sistem informasi geografis peringatan dini bencana geologi yang diimplementasikan ke dalam prototype aplikasi. Prototype aplikasi yang dikembangkan terdiri 
dari dua platform. Hasil percobaan fungsional menunjukan, prototype aplikasi yang dikembangkan mampu menghasilkan informasi: lokasi terjadinya bencana, menampilkan informasi rute menuju titik evakuasi, dan panduan keselamatan ketika terjadi bencana.

Pada umumnya, setelah bencana terjadi, orang akan mengumpulkan informasi untuk memantau situasi terkini karena cara tradisional sangat sulit diakses seperti televisi, koran, dan radio sehingga mobile phone menjadi prioritas utama selama bencana terjadi dan bisa dibawa ke lokasi pengungsian. Penggunaan mobile phone yang dilengkapi dengan aplikasi seluler tertentu akan memberikan peringatan, penginderaan lokasi, pemetaan bahaya, dan pesan bencana (Sukhwani \& Shaw, 2020).

Selain penggunaan mobile phone, intervensi lain yang dapat digunakan adalah dengan memanfaatkan media massa. Ada dua jenis media utama yang ada, yaitu media elektronik dan media cetak. Media cetak memegang peranan penting dalam penyampaian informasi kepada masyarakat, khususnya masyarakat yang memiliki keterbatasan baik secara fisik maupun sosial. Metode ini dapat digunakan dalam menyampaikan informasi pada masyarakat dengan keterbatasan tertentu contohnya pada kelompok orang gangguan penglihatan (buta parsial maupun total) dan gangguan pendengaran (Twigg, 2004; World Health Organization, 2007).

Keterbatasan fisik menyebabkan kerentanan ekonomi dan sosial. Penyandang disabilitas seringkali miskin, tanpa pendidikan, terpinggirkan atau dikucilkan dalam masyarakat, dan tergantung pada orang lain. Beberapa ahli di bidang disabilitas dan pembangunan percaya bahwa karena penyandang disabilitas tidak memiliki status di komunitas mereka, maka upaya yang dilakukan oleh komunitas untuk menyelamatkan mereka dari bencana lebih sedikit. Oleh karena itu, masalah status ini menjadi akar penyebab kerentanan mereka terhadap bencana dan dampaknya (Twigg, 2004).

Intervensi selanjutnya yang ditawarkan pada hasil literatur review ini adalah PeerMentored Prep (PM-Prep). PM-Prep merupakan program kesiapsiagaan bencana yang dikembangkan, dimasukkan ke lapangan, dan diuji dalam program penelitian partisipatif berbasis masyarakat. Tujuan dari intervensi ini adalah untuk memberikan orang dewasa dengan disabilitas perkembangan yang hidup secara mandiri dalam pengetahuan, keterampilan, dan alat komunitas agar aman, mandiri, dan mampu berkomunikasi dengan keluarga dan dukungan sosial lainnya jika terjadi bencana. Kurikulum dirancang untuk kebutuhan belajar orang dewasa yang memiliki disabilitas perkembangan. Pelatihan berbasis audio-visual mendominasi dan dikombinasikan dengan interaktif, pada kegiatan langsung yang dipimpin oleh mentor sebaya (Eisenman et al., 2014).

Pengetahuan dan sikap menjadi tolak ukur dalam mengetahui keefektifan dari intervensi yang diberikan. Kedua hal tersebut penting untuk menciptakan suatu panduan individu yang bermanfaat ketika fase bencana terjadi. Hal tersebut sejalan dengan dampak bencana secara sosial maupun psikologis yang tidak dapat diprediksikan. Kesiapan terhadap bencana perlu dilakukan untuk meminimalisir dampak dan mencapai kesejahteraan masyarakat. Hal tersebut dapat dicapai dengan melakukan program edukasi atau pelatihan bagi masyarakat dan memberikan dukungan secara mental dan materiil dari sektor-sektor daerah terkait (Brooks, et.al 2016).

Dalam manajemen risiko bencana, masyarakat dalam suatu komunitas perlu membuat rencana aksi yang konkrit terhadap suatu bencana melalui diskusi yang bermanfaat. Seorang fasilitator harus mengelola diskusi dari sudut pandang regionalitas dan umum, untuk memastikan bahwa keduanya ditangani pada waktu yang tepat (Chosokabe et al., 2017).

Peran utama dari diskusi kelompok kecil dalam proses manajemen risiko bencana adalah untuk membuat rencana pencegahan bencana yang konkrit dan praktis bagi suatu komunitas agar dapat beralih dari teori menjadi tindakan. Pada diskusi kelompok, fasilitator membantu kelompok mengklarifikasi tujuan diskusi, melakukan diskusi yang produktif, dan memutuskan langkah selanjutnya (Rees, 2005).

Dalam konteks ini, informasi lokal merupakan pengetahuan praktis yang didasarkan pada pengalaman lokal. Ilmuwan secara teratur mengabaikan kearifan lokal ini, sementara penduduk kurang memperhatikan data ilmiah, karena kurangnya budaya bertukar informasi dan komunikasi di antara mereka (Spiekermann et al., 2015). 
diskusi Ada empat tahapan penting dalam mengklarifikasi masalah dan mengembangkan alternatifnya. Pada tahap pertama, "Introducing" (1), fasilitator menjelaskan tema dan tujuan diskusi. Pada fase kedua, "Developing" (2), dia mengajak peserta untuk mendiskusikan tema dari berbagai sudut pandang. Pada fase ketiga dan keempat, "Mengumpulkan" (3) dan "Meringkas" (4), fasilitator perlu mengarahkan peserta menjauh dari diskusi luas tentang berbagai topik dan menuju fokus pada topik yang relevan dengan pertimbangan alternatif (Morisaki et al., 2014).

Diskusi kelompok kecil sangat cocok karena memberikan kesempatan untuk mengatasi kecemasan peserta atas kehilangan kendali dan untuk mengklarifikasi ketidakpastian dan kesalahpahaman tentang rencana komunikasi. fasilitator perlu menggunakan pengetahuan budaya dan peran kepemimpinannya dalam komunitas untuk menjadi model perilaku, mengatasi hambatan, dan mendorong perubahan (Eisenman et al, 2009).

\section{KESIMPULAN DAN SARAN}

Tinjauan ini menemukan 4 poin penting sebagai intervensi yang dapat digunakan, yaitu phone-based intervention, printed media intervention, peer-mentored preparedness (PMPrep) program dan small group discussion intervention. Penelitian lebih lanjut diperlukan untuk meta-analisis dan langkah selanjutnya dalam penelitian adalah untuk menstandarisasi desain uji coba, definisi status pelatihan dan isi intervensi.

Desain studi yang direview pada tulisan ini menyediakan desain yang beragam, yaitu cross-sectional, RCT, cohort longitudinal. Temuan penting yang ditemukan dalam tinjauan memberikan hasil yang baik dari komponen intervensi yang mungkin berguna untuk diterapkan di masyarakat berisiko terdampak bencana dan kebijakan untuk meningkatkan kemampuan manajemen bencana. Keterbatasannya adalah bahwa jumlah studi yang sangat sedikit dan tidak semua studi memiliki desain clinical trial.

Ulasan studi ini menyoroti implementasi yang efektif dari pemberian informasi tentang mitigasi dan kesiapsiagaan menghadapi bencana berdasarkan penelitian empiris yang dapat diadaptasi di community- based. Selain itu, tinjauan ini juga membahas hasil yang efektif. Hal ini mungkin berguna bagi pembuat kebijakan manajemen bencana untuk mengembangkan efektivitas modifikasi penyampaian informasi dan pelatihan bagi masyarakat yang berisiko terdampak bencana.

Penulis merekomendasikan penerapan intervensi yang dapat meningkatkan kesiapsiagaan bencana pada komunitas agar terus dikembangkan. Hasil literature review memberikan pengetahuan dalam berbagai cara dalam melakukan pelatihan kesiapsiagaan bencana berbasis pada masyarakat.

\section{DAFTAR PUSTAKA}

Chosokabe, M., Tanimono, K., Tsuchiya, S., Sakakibara, H., \& Kamiya, D. (2017). Evaluation of small-group discussions from the viewpoint of regionality in disaster risk management. 2017 IEEE International Conference on Systems, Man, and Cybernetics, SMC 2017, 2017Janua, 2730-2735. https $/ /$ doi.org/ 10.1109/SMC.2017.8123039.

CRED. Natural Disasters 2019. Brussels: CRED; 2020. Available at: https://emdat.be/ sites/default/ files/ adsr_2019.pdf.

de Vet, E., Eriksen, C., Booth, K., \& French, S. (2019). An Unmitigated Disaster: Shifting from Response and Recovery to Mitigation for an Insurable Future. International Journal of Disaster Risk Science, 10(2), 179-192. https//doi.org/ 10.1007/s13753-019-0214-0.

Eisenman, David P., Glik, D., Gonzalez, L., Maranon, R., Zhou, Q., Tseng, C. H., \& Asch, S. M. (2009). Improving Latino Disaster Preparedness Using Social Networks. American Journal of Preventive Medicine, 37(6), 512-517. https://doi.org/10.1016/j.amepre.2009.07. 022.

Eisenman, David P, Glik, D., Maranon, R., Gonzales, L., \& Asch, S. (2009). Developing a disaster preparedness campaign targeting low-income Latino immigrants: focus group results for project PREP. Journal of Health Care for the Poor and Underserved, 20(2), 330345. https://doi.org/10.1353/hpu.0.0129.

Eisenman, David Paul, Bazzano, A., KoniakGriffin, D., Tseng, C., Lewis, M. A., Lamb, K., \& Lehrer, D. (2014). Peer- 
mentored preparedness (PM-Prep): A new disaster preparedness program for adults living independently in the community. Intellectual and Developmental Disabilities, 52(1), 4959. https://doi.org/10.1352/1934-955652.1.49.

Gupta, D. A. (2015). Role of Social Media in Disaster Management. IMS Manthan (The Journal of Innovations), 10(1). https://doi.org/10.18701/imsmanthan.v10 i1.5659.

IFRC. (2015). World Disasters Report 2015: Focus on Local Actors, the Key to Humanitarian Effectiveness. The International Federation of Red Cross and Red Crescent Societies (IFRC ....

Isfahani, F. Al, Sugiharto, H., Aisah, S. N., \& Gunawan, R. (2019). Sistem Informasi Geografis Peringatan Dini Bencana Geologi Berbasis Mobile. JITK (Jurnal Ilmu Pengetahuan Dan Teknologi Komputer), 5(1), 57-64. https://doi.org/ 10.33480/jitk.v5il.634.

Lai, C. H., Chib, A., \& Ling, R. (2018). Digital disparities and vulnerability: mobile phone use, information behaviour, and disaster preparedness in Southeast Asia. Disasters, 42(4), 734-760. https $/ /$ doi. org/10.1111/disa. 12279.

Morisaki, K., Tsukai, M., Namba, Y., \& Kuwano, M. (2014). An Influence of Facilitator's Discourse Management on Participant's Perception For The Conclusion. Journal of Japan Society of Civil Engineers, Ser. D3 (Infrastructure Planning and Management), 70, 28-43. https://doi.org/10.2208/jscejipm.70.28.

Organization, W. H. (2007). Effective media communication during public health emergencies: a WHO handbook. World Health Organization.

Potter, M. A., Miner, K. R., Barnett, D. J., Cadigan, R., Lloyd, L., Olson, D. K., Parker, C., Savoia, E., \& Shoaf, K. (2010). The evidence base for effectiveness of preparedness training: a retrospective analysis. Public Health Reports (Washington, D.C. : 1974), 125 Suppl 5(Suppl 5), 15-23. https//doi.org/ 10.1177/00333549101250S504.

Rees, F. (2005). The Facilitator Excellence Handbook. Wiley. https://books.google. co.id/books?id=74FMpXGeEPUC.
Ryan, B. (2017). The significance of communication in emergency management: What's changed since 2010? Australian Journal of Emergency Management, 32(1), 24-31.

Schwertner, K., Zlateva, P., \& Velev, D. (2018). Digital technologies of industry 4.0 in management of natural disasters. ACM International Conference Proceeding Series. https://doi.org/ 10.1145/3234781.3234798.

Shafiq, F., \& Ahsan, K. (2014). An ICT based Early Warning System for Flood Disasters in Pakistan. Res.J.Recent Sci., 3(October 2005), 108-118.

Spiekermann, R., Kienberger, S., Norton, J., Briones, F., \& Weichselgartner, J. (2015). The Disaster-Knowledge MatrixReframing and evaluating the knowledge challenges in disaster risk reduction. International Journal of Disaster Risk Reduction, 13, 96-108. https //doi.org/ 10.1016/j.ijdrr.2015.05.002.

Stehr, S. (2007). The changing roles and responsibilities of the local emergency manager: an empirical study. International Journal of Mass Emergencies and Disasters March, 25, $37-55$.

Sukhwani, V., \& Shaw, R. (2020). Operationalizing crowdsourcing through mobile applications for disaster management in India. Progress in Disaster Science, 5, 100052. https://doi.org/10.1016/j.pdisas.2019.100 052.

Troy, D. A., Carson, A., Vanderbeek, J., \& Hutton, A. (2008). Enhancing community-based disaster preparedness with information technology. Disasters, 32(1), 149-165. https //doi.org/ 10.1111/j. 1467-7717.2007.01032.x.

Twigg, J. (2004). Disaster risk reduction: mitigation and preparedness in development and emergency programming. Overseas Development Institute (ODI). 